\title{
Expert's comment concerning Grand Rounds case entitled "Tophaceous gout of the lumbar spine mimicking a spinal meningioma" by Pedro Ribeiro da Cunha Ferreira, António Judice Peliz, and Marcos Barbosa (Eur Spine J, 2016; DOI 10.1007/s00586-016-4831-7)
}

\author{
Heba Ibrahim Ali ${ }^{1}$
}

Received: 25 October 2016/ Accepted: 26 October 2016/Published online: 17 November 2016 (C) The Author(s) 2016. This article is published with open access at Springerlink.com

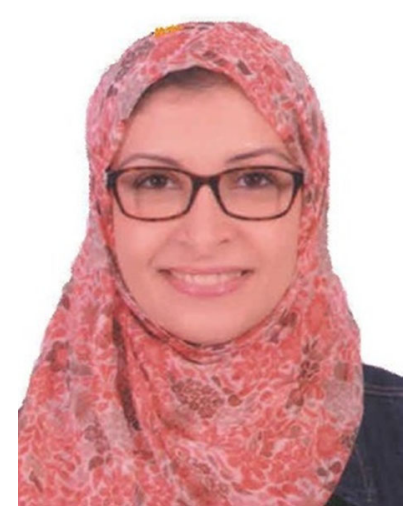

The authors present an interesting case of a 77-year-old man with a history of gout presented with chronic low back pain and progressive paraparesis [1]. Imaging showed compressive mass lesion with a dural tail at the lumbar spine mimicking meningioma, but histopathological result revealed the diagnosis of tophaceous gout. Therefore, the article highlights the possibility of gout to involve the spine and appears as intradural extramedullary mass lesion similar to meningioma and thus to correlate the given radiological findings with the clinical data.

Tophaceous gout uncommonly affects the axial skeleton [2]. Spinal gout was first described by Kersley et al. [3] in 1950, and in 1953 by Koskoff et al. [4].

Gout may affect any spinal structure of the spine, such as intervertebral discs, facet joints, laminae, vertebral

Heba Ibrahim Ali

hebaali_m@hotmail.com

1 Radiology Department, Ain Shams University, Ramsis Street, Cairo, Egypt bodies, pedicles, ligamentum flavum, filum terminale, and the soft tissues adjacent to the spinal column [5].

In case of spinal gout, X-rays may be normal or reveal soft tissue edema. Computed tomography may show erosions located in facet joints [6] and damage to soft tissue with the presence of low-density nodule or mass in some cases [7].

Konatalapalli et al. [8] retrospectively reviewed 64 CT images of the spine from patients with gout and found out that $14 \%$ of them presented features of spinal gout.

The authors mentioned the role of dual-energy CT with high sensitivity $(91.9 \%)$ and specificity $(85.4 \%)$ identifying gout tophi; the authors also stated that in the majority of cases, definitive diagnosis of gout can only be made by histological examination of the biopsy material, this, in my point of view, is very important to stress on the rule of dual-energy CT in the cases of intradural lesions. In every day practice, when we encounter a case of spinal intradural extramedullary soft tissue lesion by MRI, we rarely recommend CT scan.

Spinal tumors account for only approximately $5-15 \%$ of the nervous system neoplasms [9]. Intradural extramedullary spinal cord tumors (IESTs) account for about $60 \%$ of the intraspinal tumors, [10] and include schwannomas [11, 12] (30\%), meningiomas [12] (25\%), neurofibromas, teratomas, lipomas, and metastatic tumors. Most of these lesions are primary. Drop metastases can be also observed at this location [13]. Most intradural extramedullary tumors are benign, and they exhibit no specific symptoms.

Primary diagnostic modality for IESTs is magnetic resonance imaging (MRI) without and with contrast enhancement. Furthermore, computerized tomography (CT) scan, thin cuts with reconstructions ("bone windows") are important to evaluate bony anatomy. 
The paper highlighted a case of intradural extramedullary soft tissue mass with enhanced dural tail diagnosed by MRI, in this context; meningioma comes on top of the differential diagnosis and here is the challenge in the diagnosis of such lesions.

Spinal meningiomas are iso- or hypointense on T1weighted images and slightly hyperintense or hypointense on T2-weighted MRI. Upon contrast application, they enhance vividly (except for a calcified part) and frequently display a "dural tail" sign. In $75 \%$ of meningiomas, calcifications were registered.

In magnetic resonance imaging (MRI), tophaceous gout is usually characterized by a homogeneous image with a signal ranging from intermediate to low on $\mathrm{T} 1$, on $\mathrm{T} 2$; it appears homogeneous and may show low or high intensity [14-17]. When contrast is used, peripheral heterogeneous or homogeneous contrast enhancement may occur, revealing reactive vascularization [14-18].

Accordingly, the image picture of meningioma and tophaceous gout is alike and differentiation depends on histopathology as stated by the authors; however, the radiologist has a role in raising the suspicion of this diagnosis whenever the clinical diagnosis of gout is mentioned. In conclusion, the clinical information is crucial and should be considered in reporting similar cases. The case also raised our attention to the rule of dural-energy CT in the diagnosis of intradural lesions.

\section{Compliance with ethical standards}

Conflict of interest No conflict of interest.

Open Access This article is distributed under the terms of the Creative Commons Attribution 4.0 International License (http://crea tivecommons.org/licenses/by/4.0/), which permits unrestricted use, distribution, and reproduction in any medium, provided you give appropriate credit to the original author(s) and the source, provide a link to the Creative Commons license, and indicate if changes were made.

\section{References}

1. Ribeirao da Cunha Ferreira P, Peliz AJ, Barbosa M (2016) Tophaceous gout of the lumbar spine mimicking a spinal meningioma. Eur Spine J. doi:10.1007/s00586-016-4831-7
2. Barrett K, Miller ML, Wilson JT (2001) Tophaceous gout of the spine mimicking epidural infection: case report and review of the literature. Neurosurgery. 48(5):1170-1172 (discussion 1172-3)

3. Kersley GD, Mandel L, Jeffrey MR (1950) Gout; an unusual case with softening and subluxation of the first cervical vertebra and splenomegaly. Ann Rheum Dis 9(4):282-304

4. Koskoff YD, Morris LE, Lubic LG (1953) Paraplegia as a complication of gout. J Am Med Assoc 152(1):37-38

5. Hasturk AE, Basmaci M, Canbay S, Vural C, Erten F (2012) Spinal gout tophus: a very rare cause of radiculopathy. Eur Spine J 21 (Suppl 4):S400-S403

6. Fenton P, Young S, Prutis K (1995) Gout of the spine. Two case reports and a review of the literature. J Bone Joint Surg Am 77(5):767-771

7. Feydy A, Liote F, Carlier R, Chevrot A, Drape JL (2006) Cervical spine and crystal-associated diseases: imaging findings. Eur Radiol 16(2):459-468

8. Konatalapalli RM, Demarco PJ, Jelinek JS, Murphey M, Gibson M, Jennings B et al (2009) Gout in the axial skeleton. J Rheumatol 36(3):609-613

9. Hufana V, Tan JSH, Tan KK (2005) Microsurgical treatment for spinal tumors. Singapore Med J 46:74-77

10. Osbom AG (1991) Handbook of neuroradiology. St Louis: Mosby: 380-2

11. Abul-Kasim K, Thurnher MM, McKeever P, Sundgren PC (2008) Intradural spinal tumours: current classification and MRI features. Neuroradiology 50:301-314

12. Duong LM, McCarthy BJ, McLendon RE, Dolecek TA, Kruchko C, Douglas LL et al (2012) Descriptive epidemiology of malignant and nonmalignant primary spinal cord, spinal meninges, and cauda equina tumors, United States, 2004-2007. Cancer 118:4220-4227

13. Quiles AM, Gómez Roselló E, Laguillo G, García R, Caro JL, Pérez FS, Pedraza S (2013) GIRONA/ES: a comprehensive review of intraspinal tumors: diagnostic, classification and radiopathologic correlation. ECR 2013 Educational Exhibit. doi:10. 1594/ecr2013/C-2112

14. Hou LC, Hsu AR, Veeravagu A, Boakye M (2007) Spinal gout in a renal transplant patient: a case report and literature review. Surg Neurol 67(1):65-73

15. Hsu CY, Shih TT, Huang KM, Chen PQ, Sheu JJ, Li YW (2002) Tophaceous gout of the spine: MR imaging features. Clin Radiol 57(10):919-925

16. Miller LJ, Pruett SW, Losada R, Fruauff A, Sagerman P (1996) Clinical image. Tophaceous gout of the lumbar spine: MR findings. J Comput Assist Tomogr 20(6):1004-1005

17. Popovich T, Carpenter JS, Rai AT, Carson LV, Williams HJ, Marano GD (2006) Spinal cord compression by tophaceous gout with fluorodeoxyglucose-positron-emission tomographic/MR fusion imaging. AJNR Am J Neuroradiol 27(6):1201-1203

18. Yen PS, Lin JF, Chen SY, Lin SZ (2005) Tophaceous gout of the lumbar spine mimicking infectious spondylodiscitis and epidural abscess: MR imaging findings. J Clin Neurosci 12(1):44-46 